\title{
Long-term satisfaction and benefits on quality of life in HIV-infected people after reparatory treatment with Aquamid ${ }^{\circledR}$ for facial Lipoatrophy
}

\author{
JA Muñoz-Moreno*1, J Puig1, CR Fumaz'1, E Negredo', MJ Ferrer ${ }^{1}$, N Pérez- \\ Álvarez ${ }^{1}$, V González-Mestre ${ }^{2}$ and B Clotet ${ }^{1}$
}

\author{
Address: ${ }^{1}$ Lluita contra la SIDA Foundation - Germans Trias i Pujol University Hospital, Barcelona, Spain and ${ }^{2}$ Plastic Surgery Department - \\ Germans Trias i Pujol University Hospital, Barcelona, Spain \\ * Corresponding author
}

\author{
from Ninth International Congress on Drug Therapy in HIV Infection \\ Glasgow, UK. 9-13 November 2008 \\ Published: 10 November 2008 \\ Journal of the International AIDS Society 2008, I I(SuppI I):PI I4 doi:I0.I I86/I758-2652-I I-SI-PII4
}

This abstract is available from: http://www.jiasociety.org/content/I I/SI/PII4

(C) 2008 Muñoz-Moreno et al; licensee BioMed Central Ltd.

\section{Background}

HIV-associated facial lipoatrophy (HAFL) is known to produce disturbances on quality of life (QOL) and emotional status in people living with HIV. Reparatory treatment with facial infiltrations has been proposed as a safe and effective strategy [1], although long-term psychological benefits remain unknown [2].

\section{Methods}

We assessed the satisfaction (SAT) and QOL in a group of 145 patients who received facial infiltrations with Aquamid $^{\circledast}$ to repair their HAFL at least 3 years before. SAT was evaluated by self-reported visual-analogue scales (adapted to: non-satisfied; mildly satisfied; satisfied; very satisfied), and QOL by the assessment of the perceived limitation in the following areas: work, family, social and sexual partner (Likert scales: 0 : no limitation; 1: low; 2: moderate; 3 : high). Adherence to antiretroviral treatment was also evaluated $(0-100 \%)$. Frequencies, cross-tables and t-tests were performed.

\section{Summary of results}

Baseline demographic and clinical data were as follow: mean age: $47.2( \pm 7.04)$ years; gender: $82.8 \%$ men; mean years since HIV diagnosis: $15.8( \pm 4.1)$; mean years since first antiretroviral treatment: $9.2( \pm 4.9)$. Severe HAFL was present in $61.8 \%$ of participants. Long-term data were collected at a mean time of $4.18( \pm 0.35)$ years after infiltra- tions. The most common adverse events included nodules $(14.6 \%)$ and indurations $(6.3 \%)$. Only one patient presented a local infection in the infiltrated area. The majority of participants $(88.9 \%)$ were satisfied or very satisfied with the results of the intervention; in patients with adverse events, this was reported in the $80.5 \%$ of subjects. With respect to limitations in different QOL areas, means of scores decreased significantly in most patients compared with rates before the intervention: work: 1.66 vs. 0.86 ( $<<0.001)$; family: 2.05 vs. 0.67 ( $<<0.001)$; social: 1.38 vs. $1.05(\mathrm{p}=0.116)$; sexual partner: 1.88 vs. 0.69 (p $<0.001$ ). Levels of adherence were substantially high: $100 \%$ in $94.4 \%$ of the total sample; a similar percentage was seen in the group of patients reporting adverse events: $100 \%$ in $97.6 \%$ subjects.

\section{Conclusion}

Long-term psychological benefits may be reached with facial reconstruction in HIV-infected people with HAFL. High levels of SAT and a good QOL were observed at least 4 years after the intervention.

\section{References}

I. Negredo E, et al.: Reconstructive treatment for antiretroviralassociated facial lipoatrophy: a prospective study comparing autologous fat and synthetic substances. AIDS Patient Care STDS 2006, 20(1 2):829-37.

2. Fumaz CR, et al:: Psychological assessment of HIV-infected patients with facial lipoatrophy before and after reparatory 
treatment. 15th International AIDS Conference, Bangkok, II-I6 July 2004. Abstract WePeB5930.

Publish with Bio Med Central and every scientist can read your work free of charge

"BioMed Central will be the most significant development for disseminating the results of biomedical research in our lifetime. " Sir Paul Nurse, Cancer Research UK

Your research papers will be:

- available free of charge to the entire biomedical community

- peer reviewed and published immediately upon acceptance

- cited in PubMed and archived on PubMed Central

- yours - you keep the copyright

Submit your manuscript here:

http://www.biomedcentral.com/info/publishing_adv.asp 